\title{
NEW DATA ON THE CHOLEVIDAE (COLEOPTERA) FROM PORTUGAL
}

\author{
I. de Faria e Silva ${ }^{*}$, J. M. Salgado $\operatorname{Costas}^{2} \&$ A. R. M. Serrano ${ }^{1}$
}

\begin{abstract}
I. de Faria e Silva, J. M. Salgado Costas \& A. R. M. Serrano. 2013. New data on the Cholevidae (Coleoptera) from Portugal. Graellsia, 69(1): 45-56.

New distributional data on 15 species of family Cholevidae are given, following pitfall trapping in four protected areas in northern, central and southern Portugal. As a result, six species are reported from this country for the first time and the occurrence of three other species is confirmed. Some aspects of the biology of each species are also reviewed. Moreover, the present state of knowledge of this family in Portugal is discussed.
\end{abstract}

Keywords: Coleoptera; Cholevidae; faunistics; distribution; new records; protected areas; Portugal.

\section{RESUMEN}

I. de Faria e Silva, J. M. Salgado Costas \& A. R. M. Serrano. 2013. Nuevos datos sobre los Cholevidae (Coleoptera) de Portugal. Graellsia, 69(1): 45-56 (en inglés).

Se aportan nuevos datos de distribución y se analizan algunos aspectos de la biología de 15 especies de la familia Cholevidae, cuyos ejemplares fueron capturados mediante trampas de caída en cuatro áreas protegidas del norte, centro y sur de Portugal. Este estudio ha permitido mencionar por vez primera seis especies y confirmar la presencia de otras tres. Además, se discute el estado actual de conocimiento de esta familia en Portugal.

Palabras clave: Coleoptera; Cholevidae; faunística; distribución; nuevos registros; áreas protegidas; Portugal.

\section{Introduction}

Not much attention has been given to the study of Cholevidae in Portugal. Paulino de Oliveira (1894) was the first author to list all five species then known to occur in this country. In the years that followed, the inventory of this family was further updated, thanks to the efforts of, among others, Barros (1907, 1913 and 1924 - with the important contribution of Fr. Ramiro das Neves), Fuente

1 Centro de Biologia Ambiental e Departamento de Biologia Animal, Faculdade de Ciências da Universidade de Lisboa. Ed. $\mathrm{C} 2,2^{\circ}$ piso, Campo Grande 1749-016 Lisboa, Portugal.

* Corresponding author e-mail: insilva@fc.ul.pt

2 Departamento de Ecología y Biología Animal. Campus As Lagoas - Marcosende, Universidad de Vigo. 36310 Vigo, España. E-mail: jmsalgadocostas@uvigo.es 
(1924) and Jeannel (1923), which were included in Seabra's Coleoptera catalogue (1943); as a result, 13 species were then reported for Portugal. During a period of 40 years not many advances had been achieved, until in 1985 Blas listed only eight species, five less than Seabra's catalogue, which was regrettably ignored by Blas. However, a few of the species reported in Seabra's catalogue should be put in doubt; most records date back to the early 20 th century and some of these species are in need of confirmation because they have not been found in Portugal ever since. Some years later, the works of Giachino and Vailati (1993), Fresneda et al. (2007) and Salgado et al. (2008) did not help increase the number of known species in Portugal, but confirmed a few very old species records and compiled some old localities of occurrence. All in all and disregarding some old records of species of unlikely occurrence, there were 16 species of Cholevidae listed to Portugal by the turn of the century, whereas 50 species are known from Spain.

The study of the Iberian Cholevidae has focused more on the highly diverse Leptodirinae, which are somewhat more appealing to entomologists, due to their remarkable adaptation to the subterranean environment and high rate of localized endemics (Fresneda et al., 2007). It is generally accepted that mainland Portugal yields a poor troglobiont fauna (Reboleira et al., 2011), including Cholevidae, of which not a single species is known as yet, in contrast with the more than 160 species known from Spain. It is a fact that the Portuguese Cholevidae fauna is less diverse than that of Spain, mostly due to its lower area and its location west of the main latitudinal migration routes during paleoclimatic events. Nonetheless, we think that the low number of Cholevidae non Leptodirinae species recorded so far in Portugal can be partly attributed to the little or nonexistent collecting (or study) effort dedicated to these beetles, which can also be inferred from the low number of records in the literature from the last 100 years.

With this study we aim to contribute to the knowledge of family Cholevidae in Portugal, with data obtained during the course of a $\mathrm{PhD}$ project concerning the use of Coleoptera in biodiversity assessment studies and reserve selection. In total, collection records for 15 species are given, 6 of which are herein reported for Portugal for the first time. The occurrence of 3 other species, whose sole known records were very old and considered doubtful by some authors, is confirmed as well. A provisional checklist of all species registered so far in Portugal is also given.

\section{Material and methods}

Field work was carried out in 2001, 2002 and 2003, in northern, central and southern Portugal, respectively, in four protected areas: Douro Internacional Nature Park (PNDI), Serras d'Aire e Candeeiros Nature Park (PNSAC), Paúl do Boquilobo Nature Reserve (RNPB) and Vale do Guadiana Nature Park (PNVG). The most representative habitats in each reserve were sampled, about 15 overall. Altitude ranged from $20 \mathrm{~m}$ in the alluvial plains of RNPB up to $800 \mathrm{~m}$ in the high plateaus of PNDI. Figure 1 shows the nature parks studied and sampling site locations (or rather, their respective UTM 10x10 km square locations) where Cholevidae specimens were found. Table 1 lists the sampling sites, their locations and main habitat characteristics. Unbaited plastic pitfall traps with an $8 \mathrm{~cm}$ diameter mouth opening, filled with ethylene glycol and some drops of detergent, were used. The traps were laid out in a row of eight in every site, except for the cork-oak forest in RNPB, in which eight rows of four traps were used. Sampling took place continuously, from the beginning of February to early December (long-term sampling), except in a small number of sites in PNDI, PNSAC and RNPB, which were only sampled during one month, between mid May and mid June (short-term sampling) (see "Sampling Effort" column on Table 1). Trap contents were collected every fortnight. All Cholevidae specimens were identified to species level. The study material is deposited at the Faculty of Sciences, Lisbon University.

\section{Results}

A total of 3012 specimens of Cholevidae were captured belonging to 8 genera and 15 species, listed next. Collection data are presented as follows: site code, date, number of specimens and sex. We present as well some aspects on the biology of the species and the known geographical distribution, including known records for Portugal (locality, municipality and province, whenever possible). Chorological categories follow Vigna-Taglianti et 


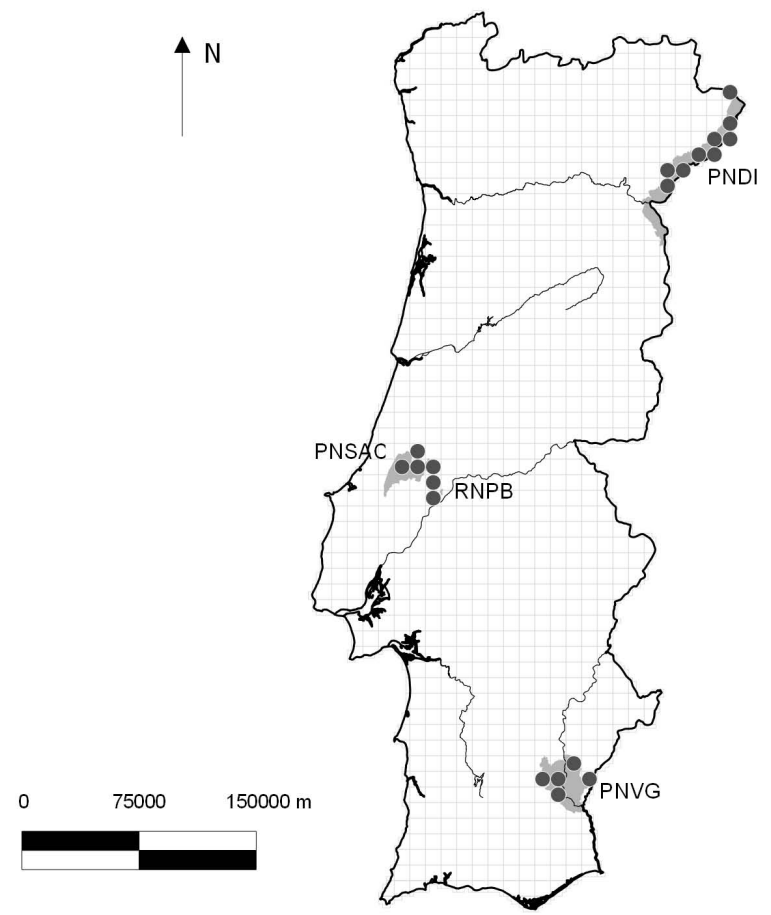

Fig. 1.- Location of the four nature reserves studied and the UTM $10 \times 10 \mathrm{~km}$ squares where Cholevidae were collected (each circle may correspond to more than one sampling site).

Fig. 1.- Localización geográfica de las cuatro áreas protegidas estudiadas y las cuadrículas UTM 10×10 km donde los Cholevidae han sido colectados (cada círculo puede corresponder a más de una localidad de muestreo).

al. (1999), with slight adaptations. Species world and Iberian distribution data were obtained from Jeannel (1936), Blas (1979), Perreau (2004), Fresneda et al. (2007) and Salgado et al. (2008). Classification and species names are according to Salgado et al. (2008).

Subfamily Anemadinae Hatch, 1928

Tribe Anemadini Hatch, 1928

Genus Speonemadus Jeannel, 1922

Speonemadus transversostriatus (Murray, 1856)

EXAMINED MATERIAL: PNDI - PIR: 14-XI-2001, 1 ㅇ․

CHOROTYPE: Iberian.

This seemingly rare species is only known from the western Iberian Peninsula, and for more than a century was thought to be endemic to Portugal, until Blas (1979) studied some specimens from
Orense province, Galicia. In Portugal S. transversostriatus is mostly known from locations north of the Tagus River: Mata do Buçaco (Mealhada, Beira Litoral), Cantanhede (Beira Litoral), Gruta de Nossa Senhora da Luz (Rio Maior, Ribatejo), S. Martinho de Anta (Sabrosa, Trás-os-Montes e Alto Douro) (Barros, 1907; Jeannel, 1936; Jeannel, 1941; Giachino \& Vailati, 1993), Peneda-Gerês National Park (9-I-1981, $10^{\pi}, 1$ \% , T. Branco leg.) and Peneda-Gerês National Park, Mata de Albergaria (Terras de Bouro, Minho) (30-I-1981, $10^{\pi}$, T. Branco leg.). South of the Tagus River it has only been detected twice, in the Arrábida Mountain Chain (Estremadura): Mata do Vidal, 14-XI-1977, $40^{7} \sigma^{\pi}, 2$ exx., A. Serrano leg. (Serrano, 1981); 5XI-1987, $10^{\prime}, 1$ ㅇ, T. Branco leg. Not much is known in particular on its biology, except that it is a lucifugous species (like other Speonemadus spp.), found under leaf litter, at times under bark (especially in decaying trees) or in the shallower sections of caves (Barros, 1907; Jeannel, 1941; Blas, 1979; Serrano, 1981; Salgado et al., 2008).

Speonemadus vandalitiae (Heyden, 1870)

EXAMINED MATERIAL: PNDI - ALR: 18-IV-2001, $10^{\pi}$; 31-X2001, 1 우; 14-XI-2001, 1 우. BRP: 4-IV-2001, 1 우; 16-V2001, 10; ; 17-X-2001, $10^{\circ}, 4$ 우 우; 31-X-2001, 2 우 우; 14-XI-2001, 2 우 우. PAE: 13-VI-2001, 1 우 . PIP: 28-II-2001, 1 우 ; 4-IV-2001, 1 우 ; 17-X-2001, $30^{7} \sigma^{7}, 1$ 우 ; 14-XI-2001, 1 오. TOC: 7-II-2001, 1 우 ; 21-II-2001, 1 우; 21-III-2001, $2 \sigma^{\top} \sigma^{\top}, 2$ 우 우 ; 4-IV-2001, $20^{\top} \sigma^{\top}, 2$ 우 우; 5-IX-2001, 1 우; 17 X-2001, 1 우; 14-XI-2001, 1 오. PNSAC - BAP: 12-II-2002, 1 ㅇ ; 26-II-2002, 1 우 ; 26-III-2002, 2 우 우 ; 9-IV-2002, $20^{7} \sigma^{7}$; 23-IV-2002, $10^{7}, 2$ 우 우; 7-V-2002, $10^{\pi} ;$ 21-V-2002, 2 우 우; 22-X-2002, 1 우.

Chorotype: W-Mediterranean.

This species inhabits Iberia, the French Pyrenees and Mallorca. In the Iberian Peninsula it is widely distributed, but there are no records from the northeastern region and only recently has it been found in southwestern Spain (Sáez \& Blanco, 2010). In our study not a single specimen was detected in the southern nature reserve. Although it has been known to Portugal for a long time, from S. Martinho de Anta (Sabrosa, Trás-os-Montes e Alto Douro) (Barros, 1907), this record was neglected by Blas (1985); nevertheless, the presence of this species has been later confirmed by Giachino \& Vailati (1993). Also recorded from Rebordãos (Bragança, Trás-os-Montes e Alto Douro), Serra da Estrela (Manteigas, Beira Alta) and Murça (Trásos-Montes e Alto Douro) (Giachino \& Vailati, 1993). We have also studied one specimen from the 
Table 1.- Cholevidae collection sites and main characteristics. SE - Sampling Effort (long-term, L, or short-term, S).

Tabla 1.- Localidades de muestreo de Cholevidae y principales características. SE - Esfuerzo de Muestreo (larga duración, L, o corta duración, S).

\begin{tabular}{|c|c|c|c|c|c|c|c|c|}
\hline Site code & $\begin{array}{l}\text { Nearest locality/ } \\
\text { Municipality }\end{array}$ & Province & $\begin{array}{l}\text { Nature } \\
\text { Reserve }\end{array}$ & $\underset{(10 \times 10)}{\text { UTM }}$ & SE & $\begin{array}{l}\text { Altitude } \\
(\mathrm{m})\end{array}$ & Habitat & Year \\
\hline ALR & $\begin{array}{l}\text { Algosinho/ } \\
\text { Mogadouro }\end{array}$ & $\begin{array}{l}\text { Trás-os-Montes } \\
\text { e Alto Douro }\end{array}$ & PNDI & 29TOF07 & L & 620 & $\begin{array}{l}\text { Stream bank with Fraxinus } \\
\text { angustifolia and Salix salvifolius }\end{array}$ & 2001 \\
\hline BEZ & $\begin{array}{l}\text { Bemposta/ } \\
\text { Mogadouro }\end{array}$ & $\begin{array}{l}\text { Trás-os-Montes } \\
\text { Alto Douro }\end{array}$ & PNDI & 29TOF17 & $S$ & 450 & $\begin{array}{l}\text { Mixed wood (mainly } \\
\text { Juniperus oxycedrus) }\end{array}$ & 2001 \\
\hline BRP & $\begin{array}{l}\text { Bruçó/ } \\
\text { Mogadouro }\end{array}$ & $\begin{array}{l}\text { Trás-os-Montes } \\
\text { e Alto Douro }\end{array}$ & PNDI & 29TPF96 & L & 750 & $\begin{array}{l}\text { Douglas fir (Pseudotsuga } \\
\text { menziesii) stand }\end{array}$ & 2001 \\
\hline $\mathrm{COC}$ & $\begin{array}{l}\text { Constantim/ } \\
\text { Miranda do Douro }\end{array}$ & $\begin{array}{l}\text { Trás-os-Montes } \\
\text { e Alto Douro }\end{array}$ & PNDI & 29TQG21 & $S$ & 800 & $\begin{array}{l}\text { Pyrenean oak wood } \\
\text { (Quercus pyrenaica) }\end{array}$ & 2001 \\
\hline FAM & $\begin{array}{l}\text { Fonte d'Aldeia/ } \\
\text { Miranda do Douro }\end{array}$ & $\begin{array}{l}\text { Trás-os-Montes } \\
\text { e Alto Douro }\end{array}$ & PNDI & 29TQF18 & L & 700 & $\begin{array}{l}\text { Cork oak (Quercus suber) forest } \\
\text { ("montado") with Cistus ladanifer layer }\end{array}$ & 2001 \\
\hline FRA & $\begin{array}{l}\text { Freixiosa/ } \\
\text { Miranda do Douro }\end{array}$ & $\begin{array}{l}\text { Trás-os-Montes } \\
\text { e Alto Douro }\end{array}$ & PNDI & 29TQF29 & $S$ & 700 & $\begin{array}{l}\text { Mixed wood (Quercus ilex } \\
\text { and J. oxycedrus) }\end{array}$ & 2001 \\
\hline LAC & $\begin{array}{l}\text { Lagoaça/Freixo de } \\
\text { Espada à Cinta }\end{array}$ & $\begin{array}{l}\text { Trás-os-Montes } \\
\text { e Alto Douro }\end{array}$ & PNDI & 29TPF96 & $S$ & 350 & $\begin{array}{l}\text { Mixed wood with chestnut } \\
\text { (Castanea sativa) and maritime } \\
\text { pine (Pinus pinaster) plantation }\end{array}$ & 2001 \\
\hline LAR & $\begin{array}{l}\text { Lamoso/ } \\
\text { Mogadouro }\end{array}$ & $\begin{array}{l}\text { Trás-os-Montes } \\
\text { e Alto Douro }\end{array}$ & PNDI & 29TQF07 & $S$ & 450 & $\begin{array}{l}\text { Stream bank (Fraxinus angustifolia } \\
\text { and Salix salvifolius) }\end{array}$ & 2001 \\
\hline MAG & $\begin{array}{l}\text { Mazouco/Freixo } \\
\text { de Espada à Cinta }\end{array}$ & $\begin{array}{l}\text { Trás-os-Montes } \\
\text { e Alto Douro }\end{array}$ & PNDI & 29TPF85 & L & 730 & Cytisus spp. shrublands & 2001 \\
\hline PAE & $\begin{array}{l}\text { Palão/Freixo de } \\
\text { Espada à Cinta }\end{array}$ & $\begin{array}{l}\text { Trás-os-Montes } \\
\text { e Alto Douro }\end{array}$ & PNDI & 29TPF85 & L & 630 & $\begin{array}{l}\text { Eucalyptus globulus plantation with } \\
\text { Cytisus spp. understorey }\end{array}$ & 2001 \\
\hline PIP & $\begin{array}{l}\text { Picotino/Freixo de } \\
\text { Espada à Cinta }\end{array}$ & $\begin{array}{l}\text { Trás-os-Montes } \\
\text { e Alto Douro }\end{array}$ & PNDI & 29TPF86 & L & 740 & Pinus pinaster plantation & 2001 \\
\hline PIR & $\begin{array}{l}\text { Picote/ } \\
\text { Miranda do Douro }\end{array}$ & $\begin{array}{l}\text { Trás-os-Montes } \\
\text { e Alto Douro }\end{array}$ & PNDI & 29TQF28 & L & 610 & $\begin{array}{l}\text { Rocky slope with some shrubs, } \\
\text { over Douro River canyon }\end{array}$ & 2001 \\
\hline TOC & Tó/Mogadouro & $\begin{array}{l}\text { Trás-os-Montes } \\
\text { e Alto Douro }\end{array}$ & PNDI & 29TQF07 & L & 690 & Young Quercus pyrenaica forest & 2001 \\
\hline VCP & $\begin{array}{l}\text { Vila Chã da Braciosa/ } \\
\text { Miranda do Douro }\end{array}$ & $\begin{array}{l}\text { Trás-os-Montes } \\
\text { e Alto Douro }\end{array}$ & PNDI & 29TQF28 & L & 710 & Fallow in cereal pseudo-steppe & 2001 \\
\hline BAE & $\begin{array}{l}\text { Barrenta/ } \\
\text { Porto de Mós }\end{array}$ & Estremadura & PNSAC & 29SND28 & L & 380 & $\begin{array}{l}\text { Eucalyptus globulus plantation with } \\
\text { Erica sp. understorey }\end{array}$ & 2002 \\
\hline BAP & Bairro/Ourém & Beira Litoral & PNSAC & 29SND37 & L & 320 & Pinus pinaster plantation & 2002 \\
\hline MIP & $\begin{array}{l}\text { Mira d'Aire/ } \\
\text { Porto de Mós }\end{array}$ & Estremadura & PNSAC & 29SND27 & L & 190 & $\begin{array}{l}\text { Polje, with orchards and Crataegus } \\
\text { monogyna, winter flooded }\end{array}$ & 2002 \\
\hline SAO & $\begin{array}{l}\text { Serra de Santo } \\
\text { António/Alcanena }\end{array}$ & Ribatejo & PNSAC & 29SND27 & $S$ & 360 & Olea europaea plantation & 2002 \\
\hline Svc & $\begin{array}{l}\text { Serro Ventoso/ } \\
\text { Porto de Mós }\end{array}$ & Estremadura & PNSAC & 29SND17 & L & 370 & Quercus faginea forest remnant & 2002 \\
\hline VGM & $\begin{array}{l}\text { Vale Garcia/ } \\
\text { Torres Novas }\end{array}$ & Ribatejo & PNSAC & 29SND37 & L & 270 & $\begin{array}{l}\text { Quercus coccifera and Cistus } \\
\text { ladanifer shrubland }\end{array}$ & 2002 \\
\hline PBC & $\begin{array}{l}\text { Azinhaga - Paúl } \\
\text { Boquilobo/Golegã }\end{array}$ & Ribatejo & RNPB & 29SND36 & $S$ & 20 & Populus nigra stand, winter flooded & 2002 \\
\hline PBM & $\begin{array}{l}\text { Azinhaga - Paúl } \\
\text { Boquilobo/Golegã }\end{array}$ & Ribatejo & RNPB & 29SND36 & L & 20 & $\begin{array}{l}\text { Cork oak (Quercus suber) "montado" } \\
\text { with Cistus ladanifer layer }\end{array}$ & 2002 \\
\hline PBS & $\begin{array}{l}\text { Azinhaga - Paúl } \\
\text { Boquilobo/Golegã }\end{array}$ & Ribatejo & RNPB & 29SND35 & L & 20 & $\begin{array}{l}\text { Salix spp. alluvial forest, flooded } \\
\text { throughout most of autumn, winter } \\
\text { and early spring }\end{array}$ & 2002 \\
\hline ALA & Algodôr/Mértola & Baixo Alentejo & PNVG & 29SPB07 & L & 180 & $\begin{array}{l}\text { Holm oak (Quercus ilex) "montado" } \\
\text { with Cistus ladanifer layer }\end{array}$ & 2003 \\
\hline CAP & Mértola & Baixo Alentejo & PNVG & 29SPB16 & L & 60 & Pinus pinea plantation & 2003 \\
\hline $\mathrm{COZ}$ & $\begin{array}{l}\text { Cortegafo - } \\
\text { "Corredoura"/Mértola }\end{array}$ & Baixo Alentejo & PNVG & 29SPB17 & L & 30 & $\begin{array}{l}\text { Arborescent shrubland with Juniperus } \\
\text { turbinata and Olea europaea sylvestris } \\
\text { (among others), overlooking the } \\
\text { Guadiana River banks }\end{array}$ & 2003 \\
\hline PFM & Mértola & Baixo Alentejo & PNVG & 29SPB16 & L & 70 & $\begin{array}{l}\text { Cork oak (Quercus suber) "montado" } \\
\text { with Cistus ladanifer layer }\end{array}$ & 2003 \\
\hline RLM & $\begin{array}{l}\text { Monte de Pias - } \\
\text { Ribeira de Limas/ } \\
\text { Serpa }\end{array}$ & Baixo Alentejo & PNVG & 29SPB28 & L & 100 & Cistus ladanifer shrublands & 2003 \\
\hline SDE & $\begin{array}{l}\text { São Domingos/ } \\
\text { Mértola }\end{array}$ & Baixo Alentejo & PNVG & 29SPB37 & L & 130 & $\begin{array}{l}\text { Eucalyptus globulus plantation with } \\
\text { Cistus ladanifer }\end{array}$ & 2003 \\
\hline
\end{tabular}


locality of Palheiros (Murça, Trás-os-Montes e Alto Douro, UTM 29TPF38, 21-IV-2010, 1 ㅇ ), which was deposited in AS's collection at the Faculty of Sciences.

Speonemadus vandalitiae is a humicolous species, usually found in woods, under thick piles of dead leaves. On occasions it shelters under bark and frequently penetrates into caves, where it inhabits the most superficial zones (Blas, 1979; Giachino \& Vailati, 1993; Salgado et al., 2008). Our specimen from Palheiros, Murça was hand collected by AS between layers of shale. Despite being generally saproxylophilous, it has been seen feeding under small vertebrate cadavers (Salgado et al., 2008). More recently it was detected in a wood mouse (Apodemus sylvaticus) nest in the province of Badajoz, Spain, together with Nargus algiricus and Catops fuliginosus (Sáez \& Blanco, 2010). To our knowledge, this is the first reported case of pholeophily in the genus Speonemadus.

In our study it was detected in low numbers and only in a few woodland sites, namely the pyrenean oak and the three coniferous forests. These results are somewhat different from those obtained in the Cantabrian Mountains, where this species is generally very abundant and eclectic in terms of habitat choice. It is even able to adapt to open habitats such as meadows, heathlands and broom shrublands, albeit at higher altitudes and therefore moister conditions than in our study (Salgado \& Fernández, 1998; Tizado \& Salgado, 2000; Salgado et al., 2008).

Subfamily Cholevinae Kirby, 1837

Tribe Cholevini Kirby, 1837

Genus Catopsimorphus Aubé, 1850

Subgenus Attiscurra Des Gozis, 1886

Catopsimorphus (Attiscurra) marqueti Fairmaire, 1857

EXAMINED MATERIAL: PNDI - VCP: 16-V-2001, 1 오.

ChOROTYPE: W-Mediterranean.

This myrmecophilous beetle occurs in southern France, the Iberian Peninsula and Morocco. Records from Spain are scarce but more or less scattered throughout, whereas in Portugal it had only been recorded from one confirmed locality, Penamaior (Paços de Ferreira, Douro Litoral) (Jeannel, 1936). This was the hometown of Fr. Ramiro das Neves, one of the pioneers of the study of Coleoptera in Portugal. By mistake, Penamaior has been systematically cited as Penamacor (Beira
Baixa) in several works (Jeannel, 1936; Blas, 1979; Fresneda et al., 2007). Some other species are cited for the province of Beira Baixa in Fresneda et al. (2007), without further location details; however, considering the scarcity of Portuguese Cholevidae records, these citations undoubtedly result from the same mistake and therefore correspond to the same collections made by Fr. Ramiro in Penamaior, Douro Litoral.

Catopsimorphus marqueti is a species of difficult detection due to its being frequently associated with nests of Messor barbarus (Blas, 1979; Salgado et al., 2008). However, it can also be found under grass tussocks, inside the cracks of clay soils (Jeannel, 1936) and sometimes even in caves (Blas, 1979).

Genus Choleva Latreille, 1797

Subgenus Choleva Latreille, 1797

Choleva (Choleva) jeanneli Britten, 1922

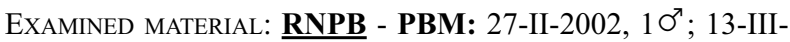
2002, $10^{\pi}$.

Chorotype: CW-European.

Distributed throughout western Europe and also most of central Europe, although rarer and more sporadic (Jeannel, 1936). In Spain it is apparently more common in the northern half, although a single specimen was recently observed in Badajoz (Sáez \& Blanco, 2010). It is seemingly absent from the eastern regions. In Portugal it was only known from the Monchique Mountain Range (Monchique, Algarve) and Mata do Choupal (Coimbra, Beira Litoral) (Jeannel, 1936; Seabra, 1939).

Choleva jeanneli lives in a wide range of habitats, probably alternating an epigeic life in mammal nests with a subterranean life in caves, like other congeners. It is frequently collected at the entrance of caves, among fallen leaves or under stones (Salgado, 1996; Salgado et al., 2008).

Subgenus Cholevopsis Jeannel, 1922

Choleva (Cholevopsis) punctata punctata C. Brisout, 1866 EXAMINED MATERIAL: RNPB - PBM: 10-IV-2002, $10^{\pi}$.

Chorotype: Iberian (including the French slope of the Pyrenees).

New species record for Portugal.

This species has been collected from several provinces in the northern half of Spain, but has also been found in one department of the French Pyrenees. Our finding is noteworthy, owing to this 
being the southernmost known locality for this species in Iberia. Furthermore, it lies $300 \mathrm{~km}$ away from the closest known locality of occurrence.

Little is known on its biology, but given that some of the findings took place in caves it can be inferred that, similarly to other species of Choleva, it might alternate between epigeal and hypogeal life stages (Blas, 1979). Usually it prefers habitats with denser vegetation cover than the preceding species, C. jeanneli (Salgado \& Fernández, 1998).

Genus Nargus Thomson, 1867

Subgenus Demochrus Thomson, 1867

Nargus (Demochrus) wilkinii (Spence, 1813)

EXAMINED MATERIAL: PNDI - TOC: 21-II-2001, 2 우 9 ; 7-III2001, 10 ; 21-III-2001, 2 우 ㅇ ; 17-X-2001, $10^{7}$.

CHOROTYPE: CS-European.

Confirmed occurrence in Portugal.

A Central European species, it is also present in the British Isles, Ireland and extending southwards to the Iberian, Italian and Balkan peninsulas. In Spain $N$. wilkinii was for a long time only known from Málaga. However, more recently it was found in other andalusian provinces, and also in León (Salgado \& Fernández, 1998), Albacete, Huesca (Salgado et al., 2008) and Badajoz (Sáez \& Blanco, 2010). In Portugal it was first collected one hundred years ago from S. Martinho de Anta (Sabrosa, Trás-os-Montes e Alto Douro) (Barros, 1913). The occurrence data presented herein is the second known Portuguese locality of this species.

Nargus wilkinii is a humicolous species, usually found under decaying leaves and on other vegetable debris. It has occasionally been observed in small cavities and tree holes, while also exhibiting pholeophilous habits in mammal nests, namely of rabbit and badger (Jeannel, 1936; Blas, 1979; Salgado et al., 2008; Leleup, 1947 in Sáez \& Blanco, 2010).

Tribe Catopini Chaudoir, 1845

Genus Catops Paykull, 1798

Catops coracinus Kellner, 1846

EXAMINED MATERIAL: PNDI - ALR: 13-VI-2001, $20^{\pi} 0^{\pi}, 1$ \% 27-VI-2001, 1 우. BEZ: $28-\mathrm{V}-2001,40^{7} \sigma^{7}, 3$ 우 우. BRP: $13-$ VI-2001, 1 \% ; 27-VI-2001, $10^{7}, 1$ ㅇ ; 17-X-2001, 1 \% ; 31-X2001, 1 우. FAM: 21-III-2001, $10^{7} ; 4$-IV-2001, 1 \% ;

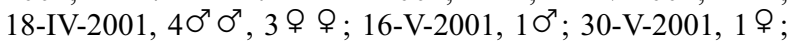

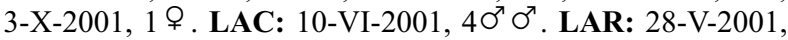
$10^{7}, 1$ 우 $11-\mathrm{VI}-2001,30^{7} 0^{7}, 6$ 우 ㅇ․ MAG: $2-\mathrm{V}-2001,10^{7}$; 13-VI-2001, $10^{7}$; 17-X-2001, 1 \% . PAE: 3-X-2001, $30^{\pi} \sigma^{\pi}$,

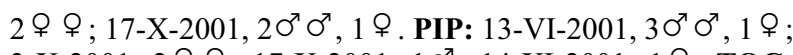
3-X-2001, 2 우 우 ; 17-X-2001, $10^{7}$; 14-XI-2001, 1 우. TOC:

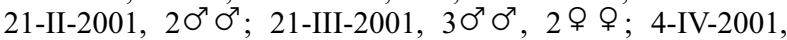
$10^{7}$; 18-IV-2001, 1 ㅇ ; 30-V-2001, $10^{\prime \prime}, 1$ क ; 3-X-2001, $10^{\prime \prime}$, $4 \circ \%$; 31-X-2001, 1 ; ; 14-XI-2001, $10^{\prime}$. PNSAC - BAE: 12 II-2002, 1 ㅇ ; 12-III-2002, $10^{7} ; 26-$-III-2002, $20^{7} \sigma^{7}, 4$ ㅇ ㅇ ; 9IV-2002, $60^{7} \sigma^{7}, 4$ 우 ㅇ 23-IV-2002, $30^{7} 0^{7}, 4$ ㅇ ㅇ; 7-V-2002, $70^{7} 0^{7}, 3$ 우 우; $21-\mathrm{V}-2002,10^{7}, 1$ 우. BAP: 12 -II-2002, $10^{7}$; 26-II-2002, $19 ; 12-$ III-2002, $10^{x}, 2 \%$; 26-III-2002, $10^{\pi}$,

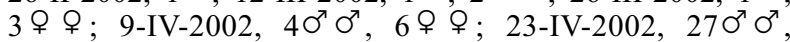
26 우 우; ; 7-V-2002, $210^{7} 0^{7}, 9$ 우 우; $21-\mathrm{V}-2002,120^{7} 0^{\text {" }}$,

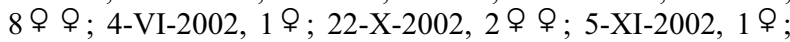
19-XI-2002,10 ; 3-XII-2002, $50^{7} 0^{7}, 1$ ㅇ․ MIP: 9-IV-2002, $10^{7}, 2$ 우 ; 23-IV-2002, 1 ㅇ ; 7-V-2002, $10^{7}$. SVC: 26-II2002, $10^{7}$, 3 ㅇ क ; 12-III-2002, $10^{7} ; 26-$-III-2002, $20^{7} 0^{7}$,

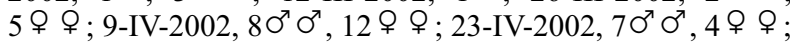
7-V-2002, $20^{\pi} \sigma^{7}, 1$ ㅇ ; 16-VII-2002, $10^{7}$. VGM: 26-II-2002, $70^{7} 0^{7}, 3$ ㅇ o ; 26-III-2002, $10^{7}, 6$ ㅇ o ; 9-IV-2002, $30^{7} 0^{7}$,

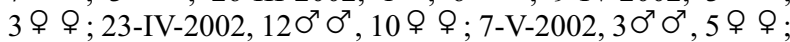
13-VI-2002, 1 \% ; 22-X-2002, $10^{\pi}, 1$; ; 5-XI-2002, $40^{\pi} 0^{\pi}$, 5 우 ; 19-XI-2002, $20^{7} 0^{7}, 3$ ㅇ 우 ; 3-XII-2002, $10^{7}$. RNPB PBM: 26-III-2002, 19 ; 10-IV-2002, $10^{7}, 19$; 24-IV-2002,

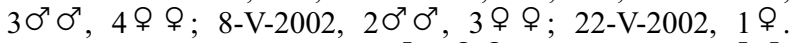
PNVG - ALA: 12-III-2003, $10^{7}, 2$ \% 9 ; 26-III-2003, $120^{7} \sigma^{7}$, 11 우 ; 9-IV-2003, $80^{7} 0^{7}, 17$ 우 우 ; 23-IV-2003, 30 $0^{7}$,

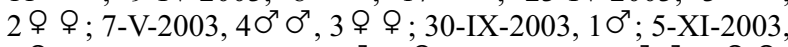
1 ㅇ. CAP: $26-\mathrm{III}-2003,10^{7}, 1$ 우 ; 9-IV-2003, $30^{7} 0^{7}, 3$ 우 웅

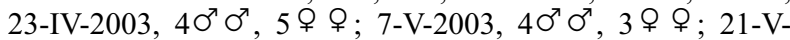
2003, 1 ㅇ. COZ: 12-III-2003, $20^{7} \sigma^{7} ;$; 26-III-2003, 1 ㅇ. PFM: 5-II-2003, 2 ㅇ 9 ; 26-II-2003, $30^{7} 0^{7}, 5$ ㅇ $~ \%$; 12-III-2003, $10^{7}$, 4 우 우 ; 26-III-2003, 1 ㅇ ; 9-IV-2003, $10^{7}, 2$ 우 우 ; 24-IV-2003, $20^{7} \sigma^{7}, 1$ 우 ; 7-V-2003, $10^{7}, 1$ 우 ; 4-VI-2003, 1 우 ; 8-X-2003, 1 ㅇ ; 22-X-2003, 3 우 ㅇ․ RLM: 26-III-2003, 1 ㅇ ; 9-IV-2003,

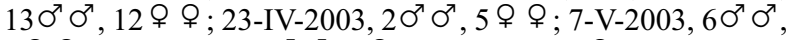

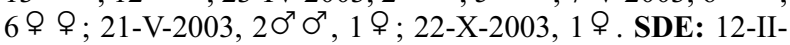
2003, $10^{7}$.

CHOROTYPE: Centralasiatic-Europeo-Mediterranean.

New species record for Portugal.

This is a widespread species occurring in Mongolia, Kazakhstan, Turkey, Israel, most of Europe and Maghreb. In Spain it is apparently present in the majority of the territory except Galicia. Catops coracinus was the second most abundant species caught in our study, alone amounting to $20 \%$ of the total Cholevidae specimens, and the most frequent, occurring in 22 out of 35 sampled sites in all four nature parks. It is remarkable that only now such a frequent and fairly abundant species was collected for the first time in Portugal. This species seemed more abundant in Serras de Aire e Candeeiros (central Portugal) and Vale do Guadiana (southern Portugal) than in Douro Internacional (northern Portugal).

Despite having been referred to as a springautumn species, at least in the Orocantabrian phytogeographic province (Salgado, 1996), only in a 
few sites there was a slight indication of a late October/early November activity peak. Depending on the site, the spring peak took place between late March and early May.

It occurred in several types of habitat, at least those with considerable vegetation cover and a leaf litter layer. The largest numbers were obtained in forests (Pinus pinaster, Eucalyptus and Quercus faginea), "montados" and even in very dry Cistus ladanifer and Quercus coccifera shrubland. As our results seem to show, it is generally considered a common species, though less common in or near the Orocantabrian phytogeographic province (Salgado, 1996; Salgado \& Fernández, 1998). Catops coracinus is reported as having wide ecological requirements (Blas, 1979; Salgado et al., 2008). It usually inhabits the litter layer and, similarly to other Catopini, is attracted to mammal and bird cadavers. Since it bears a strong attraction towards decomposing organic material, it has been found in rabbit, badger and fox burrows, and frequently shows coprophilous habits as well, preferring small mammal droppings. Rarely found in caves (Jeannel, 1936; Blas, 1979; Salgado et al., 2008).

Catops fuliginosus Erichson, 1837

EXAMINED MATERIAL: PNDI - ALR: 27-VI-2001, 1 ㅇ . BRP: 7II-2001, $1 \sigma^{7} ;$ 27-VI-2001, 1 Q . LAC: 10-VI-2001, $5 \sigma^{\pi} \sigma^{\pi}$, 1 ㅇ․ LAR: $31-\mathrm{V}-2001,5 \sigma^{\circ} \sigma^{\circ}, 1$ 우 ; 11-VI-2001, 1 오. PIP: $18-$ IV-2001, $10^{7}$; 13-VI-2001, $10^{7}$. TOC: 4-IV-2001, $10^{7}, 1$ ㅇ ; 18-IV-2001, $10^{\pi}$; 31-X-2001, 1 ㅇ․ PNSAC - BAE: 26-III-

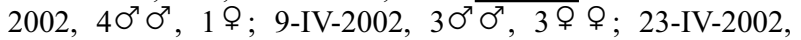
$5 \sigma^{\pi} \sigma^{\prime \prime}, 2$ 우 우 ; 7-V-2002, $3 \sigma^{\pi} \sigma^{7}$. BAP: 26-III-2003, $10^{\pi}$; 9-IV2002, $40^{7} \sigma^{\pi}, 4$ 우 우; 23-IV-2002, $80^{7} \sigma^{7}, 7$ 우 우; 7-V-2002, $160^{7} \sigma^{7}, 3$ 우 우; 21-V-2002, $90^{7} \sigma^{7}, 7$ 우 우; 9-XI-2002, 1 우. SVC: 9-IV-2002, $10^{\top}, 1$ ᄋ; 23-IV-2002, $30^{\top} \sigma^{\pi}, 1$ 우 7-V2002, $10^{\prime \prime}$.

CHOROTYPE: European.

Catops fuliginosus is present in virtually all Europe, the Caucasus and Asia Minor. In the Iberian Peninsula it is known from most of the territory, but is deemed rarer in the northwest, with no occurrences reported yet for Galicia. Before this study only two occurrences had been recorded from Portugal, both locations north of the Douro River: S. Martinho de Anta (Sabrosa, Trás-os-Montes e Alto Douro) and Penamaior (Paços de Ferreira, Douro Litoral) (Barros, 1913; Jeannel, 1936).

In our study we did not detect it in the southern nature park (PNVG). This one is clearly a spring species, at least under the bioclimatic conditions of the region studied. Only one activity peak in late
April/early May was detected.

Catops fuliginosus was only collected in woodland sites, which seems to concur with its reported preference for shaded places with a thick litter layer (Salgado, 1996; Salgado \& Fernández, 1998; Salgado et al., 2008). It seemed particularly abundant at the Pinus pinaster site in PNSAC, whose ground was densely covered with moss, a feature which is favoured by many Cholevidae (Salgado et al., 2008). This species is a generalist saprophagous, being attracted to all sorts of decaying vegetable and animal material. It feeds on small mammal and bird cadavers and mammal faeces, out in the open or inside burrows of rabbit, badger, hamster, wood mouse Apodemus sylvaticus and several vole species (Jeannel, 1936; Sáez \& Blanco, 2010). Catops fuliginosus uses caves more frequently than $C$. coracinus; in some areas of the Iberian Peninsula it behaves as a regular trogloxene and occasionally even as troglophile, near the entrance to caves (Jeannel, 1936; Blas, 1979; Salgado \& Fernández, 1998; Salgado et al., 2008).

Catops nitidicollis Kraatz, 1856

EXamined Material: PNDI - TOC: 18-IV-2001, $10^{\pi}$. CHOROTYPE: S-European.

New species record for Portugal.

Catops nitidicollis is mainly distributed in southern Europe, Asia Minor and the Caucasus. Seemingly rare throughout its distribution range, in Iberia it was only known from a small number of localities in three northern Spanish provinces (León, Álava and Lérida). Owing to its apparent rarity, not much is known of its feeding biology. Jeannel (1936) refers to this species as usually occurring in the entrances to rabbit and fox burrows, being also attracted to various mammal excrements (Salgado et al., 2008); however, the only information available for the Iberian Peninsula only reports it feeding on Boletus spp. mushrooms (Blas, 1979). Sporadically found in caves (Salgado, 1985).

Catops tristis tristis (Panzer, 1793)

EXAMINED MATERIAL: PNDI - TOC: $13-\mathrm{VI}-2001,10^{\pi}, 2$ 우 $ᄋ$. CHOROTYPE: European.

Confirmed occurrence in Portugal.

Widespread through most of Europe, it presents a continuous distribution in the northern regions, right up to the Arctic Circle. However, in southern Europe its occurrence is limited to the highest 
mountainous massifs and absent from the southernmost limits of the mediterranean peninsulas. In the Iberian Peninsula it has been recorded from several localities in the Cantabrian Mountains, the Pyrenees, the Guadarrama Mountains and also in Portugal, from Coimbra (Beira Litoral) and Buçaco (Mealhada, Beira Litoral) (Oliveira, 1894). However, the presence of this species in Portugal was considered doubtful by some authors (e.g. Fresneda et al., 2007), as it had never been observed ever since Oliveira's findings. Besides, these Portuguese locations in central western Portugal are situated at low to medium altitudes (not higher than $549 \mathrm{~m}$ ) and are characterized by a mild climate, which contrasts with the localities where $C$. tristis has been found in Spain. In fact, it is often regarded as the most orophilous Cholevidae species, preferring altitudes above 1300 m (Salgado, 1996; Salgado \& Fernández, 1998). The site where it was now found, at $690 \mathrm{~m}$, is located in the northeastern region of Portugal, which, although essentially mediterranean, has a more continental climate, with colder winters.

Catops tristis is said to possess a varied ecological range. It is frequently pholeophilous in nests of rabbit, badger, hamster, marmot and mole and has also been found in Vespula vulgaris nests. As with most pholeophilous Cholevidae, it also shows coprophilous habits, preferring nonherbivore faeces, and behaves as a necrophagous as well. In the Cantabrian Mountains, the Pyrenees and the Balkan Peninsula it is frequently found in caves (Jeannel, 1936; Blas, 1979; Salgado et al., 2008).

Catops ventricosus rotundatus Szymczakowski, 1963 EXAMINED MATERIAL: PNDI - LAR: 28-V-2001, 10 $0^{7}, 4$ 우 ㅇ. CHOROTYPE: Centraleuropean.

New species record for Portugal.

This species includes two geographically distinct subspecies. The nominotypical occurs in Turkey and the Caucasus, whereas ssp. rotundatus occurs in Iberia, Italy, France, Germany, Poland, Sweden and Slovakia. In the Iberian Peninsula it was until now only known from the western Pyrenees and the Cantabrian Mountains. Catops ventricosus is very susceptible to temperature and moisture variations, preferring habitats where these parameters are more stable, such as caves, where it has sometimes been found together with several species of Leptodirinae (Salgado et al., 2008). Also collected among vegetable debris, in the southern slope of the Cantabrian Mountains it has shown preference for low vegetation cover, such as broom shrubland and heathland, above $1100 \mathrm{~m}$ (Salgado \& Fernández, 1998). Our finding happened in a riparian gallery at $450 \mathrm{~m}$, at the bottom of a narrow escarpment valley with a waterfall, which provides for a cool and damp habitat and an abundant litter layer. Little is known of its feeding biology, other than being a generalist detritivore, also found on carcasses (Salgado \& Fernández, 1998; Salgado et al., 2008).

Genus Fissocatops Zwick, 1968

Fissocatops quadraticollis (Aubé, 1850)

EXAMINEd Material: PNDI - PIP: 17-X-2001, $10^{7}, 2$ 우 ㅇ.

CHOROTYPE: NW-Mediterranean.

New species record for Portugal.

This species has a limited distribution area, occurring only in northern Italy, western France and the Iberian Peninsula, where it was up to now only known from the Cantabrian region (Salgado et al., 2008). It frequently lives on decaying vegetable material, but has also been found feeding on decomposing mushrooms. It is also attracted to mammal droppings, most commonly fox, and has been collected in burrows of rabbit and badger (Jeannel, 1936; Blas, 1979; Salgado et al., 2008).

Genus Sciodrepoides Hatch, 1933

Sciodrepoides watsoni watsoni (Spence, 1813)

EXAMINED MATERIAL: PNSAC - BAE: 26-III-2002, $10^{7}, 19$; 9-IV-2002, 1 ㅇ ; 23-IV-2002, $60^{7} \sigma^{7}, 1$ ㅇ ; 7-V-2002, $160^{7} 0^{7}$, 6 우 우 ; 21-V-2002, $50^{x} 0^{x}$; 4-VI-2002, $20^{x} \sigma^{x}, 3$ 우 우. BAP: 21-V-2002, $10^{n}, 1$ ㅇ․ MIP: 9-IV-2002, $10^{n}, 1$ \% ; 23-IV-2002, $150^{7} \sigma^{7}, 6$ 웅; 7-V-2002, $170^{7} \sigma^{7}, 32$ 우 울 21-V-2002, $70^{\pi} 0^{\pi}, 9$ 우 ㅇ ; 4-VI-2002, $20^{7} 0^{\pi}, 3$ 우 ㅇ. SVC: 23-IV-2002,

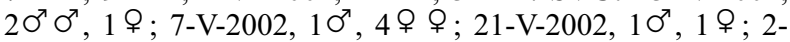
VII-2002, $20^{7} \sigma^{7}, 1$ \% . VGM: $23-I V-2002,1$ ㅇ. RNPB PBM: $10-I V-2002,10^{\pi} ; 8-\mathrm{V}-2002,20^{\pi} 0^{\pi}, 1$ 우. PBS: $22-\mathrm{X}-$ 2002,1 ㅇ․

CHOROTYPE: Asiatic-European.

Confirmed occurrence in Portugal.

Sciodrepoides watsoni presents a wide distribution range, extending from the Russian Far East, Japan, Korea and northern China over to Europe (ssp. watsoni) and eastern North America [ssp. hornianus (Blanchard, 1915)]. However, it is absent from North Africa, the Middle East (without Turkey), Central, South and Southeast Asia. Most known records come from the northern half of Iberia, and though some authors thought it absent from the western regions, including Portugal (Blas, 
1985; Fresneda et al., 2007), it had already been recorded from S. Martinho de Anta (Sabrosa, Trásos-Montes e Alto Douro) and Penamaior (Paços de Ferreira, Douro Litoral) (Barros, 1924), both localities north of the Douro River. Be that as it may, the presence of this species in Portugal is confirmed, after almost 90 years without any published records. As expected, we haven't detected it in the southern nature park (PNVG), but it was also absent from the northeasternmost region studied (PNDI); being absent from much of the southern Palaearctic, mostly dominated by desert and subdesert environments, it probably does not adapt well to drier bioclimates. These specimens taken from PNSAC, in the Estremadura Limestone Massif, are the westernmost and southernmost known locations in the Iberian Peninsula for $S$. watsoni.

Concerning the phenology of this species, only a spring activity peak was observed, between 23 April and 7 May, while Salgado (1996) recorded an additional late summer/early autumn activity period, albeit in the Cantabrian Chain. According to Blas (1979) and Salgado et al. (2008), it exhibits pholeophilous and nidicolous habits. As such, it is also necrophagous on small mammals (and other vertebrates) and coprophagous, mainly on nonherbivore droppings. Jeannel (1936) reported it from burrows of mole, rabbit, hamster and Mus spp., and from nests of thrushes and puffins. It has also been proven to occur in caves, near the entrances (Salgado, 1985).

Subfamily Ptomaphaginae Jeannel, 1911

Tribe Ptomaphagini Jeannel, 1911

Genus Ptomaphagus Hellwig, 1795

Subgenus Ptomaphagus Hellwig, 1795

Ptomaphagus (Ptomaphagus) subvillosus (Goeze, 1777) EXAMINED MATERIAL: PNDI - FAM: 13-VI-2001, $10^{\prime}, 1$ ㅇ.

CHOROTYPE: European.

New species record for Portugal.

Widespread in central, western and northern Europe, in the Iberian Peninsula it only seems to inhabit the northern half, having been reported from León, Barcelona, La Rioja and Navarra. These specimens were collected in a cork-oak montado, which agrees with Salgado and Fernández (1998), who state this species as usually found in Quercus woodlands, amidst leaf litter and moss. For the most part it has saproxylophilous habits, yet it is attracted to decaying meat as well.
Occasionally found in caves (Salgado et al., 2008).

\section{Ptomaphagus (Ptomaphagus) tenuicornis tenuicornis}

(Rosenhauer, 1856)

Examined material: PNDI - ALR: 13-VI-2001, $10^{7}, 1$ 우 ; $27-$ VI-2001, $10^{7}, 5$ 우 우. BEZ: 28-V-2001, $10^{7}$. BRP: 7-II-2001, $10^{\top}, 8$ 우 우 ; 21-II-2001, $30^{\top} \sigma^{\pi}, 2$ 우 우; 7-III-2001, 2 우 우; 21III-2001, $10^{7}, 2$ 우 우; 4-IV-2001, $60^{7} \sigma^{\pi}, 6$ 우 우; 18-IV-2001, $20^{\pi} \sigma^{\pi}, 6$ 우 우; 2-V-2001, $10^{\pi}, 3$ 우 우; 30-V-2001, $10^{\pi}, 5$ 우 우; 13-VI-2001, $72 \sigma^{\top} \sigma^{\top}, 82$ 우 우; 27-VI-2001, 455 $0^{\top} \sigma^{\top}, 497$ 우 우;

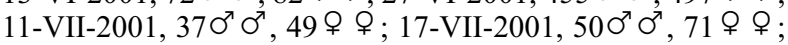

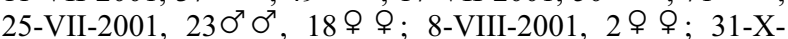
2001, $20^{\top} \sigma^{\top}, 6$ 우 우; 14-XI-2001, $10^{\top}, 2$ 우 우; 28-XI-2001, $1 \sigma^{\pi}, 1$ ㅇ․ . COC: $12-\mathrm{VI}-2001,1$ 우 ; 29-V-2001, 1 우 . FAM: $18-$ IV-2001, $1 \sigma^{\top}, 1$ ㅇ ; 30-V-2001, $24 \sigma^{\top} \sigma^{\pi}, 24$ ㅇ ㅇ ; 13-VI-2001, $140^{\top} \sigma^{\pi}, 20$ 우 우 ; 27-VI-2001, $30^{\top} \sigma^{\pi}, 2$ 우 우; 25-VII-2001, 1 우. LAC: $28-\mathrm{V}-2001,2$ 우 ; ; 10-VI-2001, $20^{7} \sigma^{\pi}, 4$ 우 우. LAR: $31-\mathrm{V}-2001,10^{\prime}, 1$ 우 ; 11-VI-2001, $60^{\pi} \sigma^{\pi}, 10$ 우 ㅇ․ MAG: 7-II-2001, 1 \% ; 21-II-2001, $10^{7} ; 30-\mathrm{V}-2001,3 \sigma^{\pi} \sigma^{\pi}$,

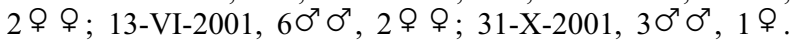
PAE: 7-II-2001, $3 \sigma^{\pi} \sigma^{\pi}, 10$ 우 우; 21-II-2001, $10^{\pi}, 5$ 우 우; 7III-2001, $2 \sigma^{7} \sigma^{7}, 2$ 우 우; 21-III-2001, 2 우 우; 4-IV-2001, $40^{7} \sigma^{\pi}, 6$ 우 우 ; 18-IV-2001, $10^{\pi} ; 2-\mathrm{V}-2001,40^{7} \sigma^{\prime \prime}, 9$ 우 우; 16-

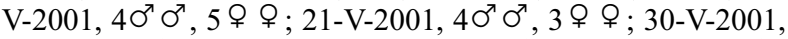

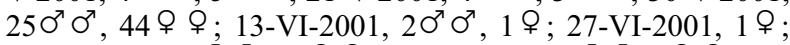
31-X-2001, $12 \sigma^{7} \sigma^{7}, 10$ 우 우; 14-XI-2001, $2 \sigma^{7} \sigma^{\top}, 2$ 우 우; 28XI-2001, 1 우. PIP: 7-II-2001, $10^{7} ;$ 21-II-2001, $10^{7}, 1$ 우 ; 7III-2001, $2 \sigma^{\top} \sigma^{7}, 3$ 우 우; 21-III-2001, 1 우 ; 18-IV-2001, $3 \sigma^{7} \sigma^{\prime \prime}$, 7 우 우; 13-VI-2001, $120^{\pi} \sigma^{\pi}, 35$ 우 우; 27-VI-2001, 56 $50^{\top} \sigma^{\prime \prime}$, 79 우 우; 11-VII-2001, $80^{7} \sigma^{\pi}, 10$ 우 우; 25-VII-2001, $10^{\pi}$, 2 우 우; 14-XI-2001, $10^{\circ}, 1$ 우. TOC: 7-II-2001, 1 우; 4-IV2001, $10^{7} ; 16-\mathrm{V}-2001,10^{7} ; 13-\mathrm{VI}-2001,10^{7}$. VCP: 7-II-2001, 1 ㅇ ; 21-II-2001, 1 ㅇ ; 4-IV-2001, $10^{\pi} ; 13-\mathrm{VI}-2001,1$ ㅇ․ PNSAC - BAE: 18-II-2002, 1 우 ; 12-III-2002, 1 ㅇ ; 26-III2002, 3 우 우; 9-IV-2002, $60^{\top} \sigma^{x}, 6$ 우 우; 23-IV-2002, $100^{\top} \sigma^{\top}$, 12 우 우; 7-V-2002, $70^{7} \sigma^{7}, 19$ 우 우; 21-V-2002, $40^{7} \sigma^{7}, 7$ 우 우; 4-VI-2002, 2 우 우; 2-VII-2002, $10^{\prime \prime}$. BAP: 12-III-2002, $10^{\sigma^{\prime}}$; 9-IV-2002, 1 ᄋ ; 23-IV-2002, $2 \sigma^{\top} \sigma^{\pi}, 1$ ㅇ ; 7-V-2002, $2 \sigma^{x} \sigma^{\pi}$, 3 우 우; 21-V-2002, $30^{7} \sigma^{7}$, 5 우 우; 4-VI-2002, 1 우; 18-VI2002, 1 오. SAO: $21-V-2002,1 \sigma^{\circ}$. SVC: $26-$ II-2002, 1 우; 26III-2002, $4 \sigma^{\pi} \sigma^{\pi}, \quad 8$ 우 우; 9-IV-2002, $2 \sigma^{\pi} \sigma^{\pi}, 9$ 우 우; 23-IV-2002, $40^{7} \sigma^{7}, 6$ 우 우; 7-V-2002, $20^{7} \sigma^{7}, 4$ 우 우 ; 2-VII2002, $10^{7}, 5$ 우 우; 16-VII-2002, $10^{7}$. VGM: 26-III-2002, 1 우;

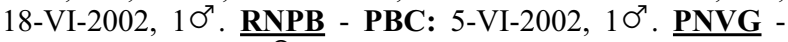
PFM: 24-IV-2003, 1 오.

CHOROTYPE: Gallo-Iberian.

This species is also present in North Africa and Sicily, where ssp. mauritanicus Jeannel, 1934 replaces the nominotypical subspecies. The latter only inhabits southern France and the Iberian Peninsula. In Iberia it is apparently widely distributed, if only somewhat discontinuous and still unknown from many regions. Before this study, in Portugal it was only known from one locality up north (Gondomar, Douro Litoral) (Blas, 1979).

Next to Catops coracinus it was the most frequent species, having shown up in 19 out of 35 sampled sites; however, it was almost absent from 
the driest habitats, such as the Cistus ladanifer and Quercus coccifera shrublands. In the semi arid region of the Guadiana valley (PNVG) only a single specimen was caught, precisely in the habitat with the richest litter layer among those sampled, the cork-oak montado. Overall, P. tenuicornis was very abundant in this study, alone accounting for $70 \%$ of all Cholevidae catches. It was much more abundant in the northeastern nature preserve (PNDI), namely in the young Pseudotsuga menziesii (Douglas fir) stand, where $2 / 3$ of the total catches of this species took place. These coniferous trees are characterized by dense canopies down to near ground level, which provide for a cool and dusky environment, devoid of ground vegetation and hardly any leaf litter. Ptomaphagus tenuicornis is essentially a spring species (Salgado, 1996; Salgado \& Fernández, 1998), and in our study its activity peak occurred from late April to late June, depending on the sampling site, although a short late October activity peak was also observed in two sampling sites. It is worth noting that the late June activity peak in the aforementioned Douglas fir site rendered a total of 952 specimens, roughly $1 / 3$ of the total Cholevidae captured in all 35 sites.

In a study on habitat choice in the Cantabrian Range, Tizado and Salgado (2000) reported $P$. tenuicornis as preferring habitats with dry leaf litter and marked substrate temperature variation. In our study, however, it was much more abundant in the Pseudotsuga menziesii stand, whose extremely umbrageous canopies probably help keep the ground temperature more stable, despite the thin litter layer and absence of ground vegetation. Essentially inhabiting the leaf litter, it also penetrates caves occasionally (Salgado, 1985), and according to Jeannel (1936) it also shows myrmecophilous habits in association with Lasius spp. Not much further is known of its biology, apart from the fact that it is frequently captured by means of traps baited with meat, liver, cheese and sour wine (Blas, 1979; Salgado \& Fernández, 1998; Salgado et al., 2008), whilst being attracted to cadavers as well (Giachino \& Tosti-Croce, 1986 in Salgado et al., 2008).

\section{Discussion}

We believe the results of this study are somewhat surprising, both for the number of species detected and the number of specimens collected. In fact, our sampling design was not particularly directed towards Cholevidae, for which various attraction substances or baits are frequently used, e.g., beer, liver, fish or cheese (Blas, 1979; Salgado, 1996; Salgado \& Fernández, 1998; Salgado et al., 2008). In addition, most studied sites lay at low to medium altitudes (our highest altitude site lay only $800 \mathrm{~m}$ a.s.1.) and are influenced by a mediterranean climate, with long and hot, dry summers; still, a few orophilous species have been detected in the northeastern protected area, two of which (Fissocatops quadraticollis and Catops ventricosus) were until then only known from the Cantabrian Mountain Chain and the Pyrenees.

With a total of seven Cholevidae species, the young Quercus pyrenaica woodland located in the Douro Internacional Nature Park was the richest site sampled, which comes as no surprise, given the abundant leaf litter this kind of forest usually produces and the preference Cholevidae have for such a microhabitat. Conversely, it was in the driest sites, with low lying vegetation and thin litter layer, that the lowest richness values were obtained. Consequently, in the dry region of the Guadiana Valley only two species were recorded.

The number of "epigean" Cholevidae (subfamilies Anemadinae, Cholevinae and Ptomaphaginae) species occurring in Portugal is thus not as low as previous works suggested (Blas, 1979; Perreau, 2004); with the present contribution the number of known Portuguese Cholevidae rises to 22. Nevertheless, we think the knowledge of this family in Portugal still has a lot to improve, as more sampling methods are employed and more habitats are sampled. Because most Cholevidae are microthermophilous and hygrophilous (Giachino \& Vailati, 1993; Salgado et al., 2008), the study of habitats located at higher altitudes and/or in more humid regions (for instance, Quercus robur forests, high altitude heathlands and broom shrublands) could yield some interesting results. Moreover, the development of biospeleology research in Portugal might also contribute to the study of this group, given that many members of the three "epigean" subfamilies may also inhabit the subterranean realm, at least for some periods of their life cycle, particularly in the more xeric karst regions (Giachino \& Vailati, 1993). 


\section{Provisional checklist of the Cholevidae of Portugal}

This checklist attempts to bring together all species so far reported to occur in Portugal. However, we have omitted some old species accounts of unlikely occurrence in Portugal which probably resulted from misidentifications. Species names marked with an asterisk $\left(^{*}\right)$ are taken from early 20th century publications and have not been found since. Nomenclature follows Salgado et al. (2008).

Subfamily Anemadinae Hatch, 1928

Tribe Anemadini Hatch, 1928

Speonemadus angusticollis (Kraatz, 1870)

Speonemadus clathratus (Perris, 1864)*

Speonemadus orchesioides (Fairmaire, 1879)

Speonemadus transversostriatus (Murray, 1856)

Speonemadus vandalitiae (Heyden, 1870)

Subfamily Cholevinae Kirby, 1837

Tribe Cholevini Kirby, 1837

Catopsimorphus (Attiscurra) marqueti Fairmaire, 1857

Catopsimorphus (Weiratherella) rougeti Saulcy, 1863*

Choleva (Choleva) fagniezi uhagoni Jeannel, 1922*

Choleva (Choleva) jeanneli Britten, 1922

Choleva (Choleva) oblonga oblonga Latreille, 1807*

Choleva (Cholevopsis) punctata punctata C. Brisout, 1866

Nargus (Demochrus) wilkinii (Spence, 1813)

Philomessor (Philomessor) brevicollis brevicollis (Kraatz, 1852)*

Tribe Catopini Chaudoir, 1845

Catops coracinus Kellner, 1846

Catops fuliginosus Erichson, 1837

Catops nitidicollis Kraatz, 1856

Catops tristis tristis (Panzer, 1793)

Catops ventricosus rotundatus Szymczakowski, 1963

Fissocatops quadraticollis (Aubé, 1850)

Sciodrepoides watsoni watsoni (Spence, 1813)

Subfamily Ptomaphaginae Jeannel, 1911

Tribe Ptomaphagini Jeannel, 1911

Ptomaphagus (Ptomaphagus) subvillosus (Goeze, 1777)

Ptomaphagus (Ptomaphagus) tenuicornis tenuicornis (Rosenhauer, 1856)

\section{Acknowledgements}

We are indebted to Pedro Cardoso, Nuno Oliveira, PNDI, PNSAC, RNPB and PNVG for fieldwork assistance. Thanks are also due to Prof. Pedro Oromí and an anonymous reviewer for their suggestions, which helped improve the manuscript significantly. We also express our gratitude to Dr. José Manuel Blanco Villero for kindly sending us one of his publications. Israel de Faria e Silva was supported by Fundação para a Ciência e Tecnologia, through SFRH/BD/6051/2001 PhD grant.

\section{References}

Barros, J. M. C., 1907. Quelques Coléoptères nouveaux pour la faune du Portugal. Bulletin de la Société Portugaise des Sciences Naturelles, 1: 130-143.

Barros, J. M. C., 1913. Adições ao Catálogo dos Coleópteros de Portugal. Brotéria, Série Zoológica, 11: 105118.

Barros, J. M. C., 1924. Notas entomológicas. Anais do Instituto de Zoologia da Universidade do Porto, 1: 311.

Blas, M., 1979. Contribución al conocimiento de los Catopidae (excepto la subfam. Bathysciinae) de la Península Ibérica (Coleoptera Staphylinoidea). Universidad de Barcelona. Tesis Doctoral (inédita). $361 \mathrm{pp}$.

Blas, M., 1985. Sobre los Catopidae de Portugal (Coleoptera). Actas do II Congresso Ibérico de Entomologia. Boletim da Sociedade Portuguesa de Entomologia, supl. 1: 169-176.

Fresneda, J., Cárdenas, A. M., Castro, A., Lencina, J. L., López-Colón, J. I. \& Baena, M., 2007. Nuevos datos de los Cholevidae en la Península Ibérica (Coleoptera). Boletín de la Asociación española de Entomología, 31(3-4): 187-214.

Fuente, J.M. de la, 1924. Catálogo sistemático-geográfico de los Coleópteros observados en la Península Ibérica, Pirineos propriamente dichos y Baleares. Boletín de la Sociedad Entomológica de España, 7(2-3): 93-121.

Giachino, P. M. \& Vailati, D., 1993. Revisione degli Anemadinae. Monografie di "Natura Bresciana", 18: $1-314$.

Jeannel, R., 1923. Révision des Choleva Latreille, pour servir à l'Histoire du peuplement de l'Europe. Abeille, 32: 1-160.

Jeannel, R., 1936. Monographie des Catopidae. Mémoire du Museum d'Histoire Naturelle. Paris. $433 \mathrm{pp}$.

Jeannel, R., 1941. Premières explorations des grottes du Portugal par M.A. de B. Machado - Coléoptères. Publicações do Instituto de Zoologia "Dr. Augusto Nobre" da Faculdade de Ciências do Porto, 4: 5-15.

Paulino de Oliveira, M., 1894. Catalogue des Insectes $d u$ Portugal: Coléoptères. Imprensa da Universidade. Coimbra. 393 pp.

Perreau, M., 2004. Leiodidae. In: I. Löbl \& A. Smetana (eds.). Catalogue of Palaearctic Coleoptera, Vol. 2. Apollo Books. Stenstrup: 133-203. 
Reboleira, A. S. P. S., Borges, P. A. V., Gonçalves, F., Serrano, A. R. M. \& Oromí, P., 2011. The subterranean fauna of a biodiversity hotspot region Portugal: an overview and its conservation. International Journal of Speleology, 40(1): 23-37. DOI: 10.5038/1827-806X.40.1.4

Sáez Bolaño, J. A. \& Blanco Villero, J. M., 2010. Los Colévidos Epigeos (Coleoptera, Leiodidae, Cholevinae) de la Sierra de Tudía (Badajoz, Extremadura, España). Boletín de la Sociedad Entomológica Aragonesa, 47: 357-361.

Salgado, J. M., 1985. Nuevos datos sobre Catopidae (Col.) capturados en cuevas. Boletín de la Asociación española de Entomología, 9: 271-277.

Salgado, J. M., 1996. Leiodidae Cholevinae (Coleoptera) in the Orocantabrian phytogeographic province (Cantabrian Cordillera, North Spain). Giornale Italiano di Entomologia, 8: 213-229.

Salgado, J. M., Blas, M. \& Fresneda, J., 2008. Coleoptera, Cholevidae. In: M. A. Ramos et al. (eds.). Fauna Ibérica, Vol. 31. Museo Nacional de Ciencias Naturales, CSIC. Madrid. 799 pp.

Salgado, J. M. \& Fernández, M., 1998. Estudio de los Leiodidae: Cholevinae (Coleoptera) en las cuencas de los ríos Bernesga, Torío y Porma (León, España). Boletín de la Asociación española de Entomología, 22(1-2): 81-97.

Seabra, A. F., 1939. Contribuição para a História da Entomologia em Portugal: Coleópteros. Publicações da Direcção Geral dos Serviços Florestais e Aquícolas, 6(2): 206-257.

Seabra, A. F., 1943. Contribuições para o Inventário da Fauna Lusitânica: Insecta, Coleoptera. Memórias e Estudos do Museu Zoológico da Universidade de Coimbra, Série 1, (142): I-XX, 1-152.
Serrano, A. R. M., 1981. Contribuição para o Estudo dos Coleópteros do Parque Natural da Arrábida. Colecção Parques Naturais, 9, Serviço Nacional de Parques, Reservas e Património Paisagístico. Lisboa. 87 pp.

Tizado, E. J. \& Salgado, J. M., 2000. Local-scale distribution of cholevid beetles in the province of León (Spain). Acta Oecologica, 21(1): 29-35. DOI: 10.1016/ S1146-609X(00)00109-0

Vigna-Taglianti, A., Audisio, P. A., Biondi, M., Bologna, M. A., Carpaneto, G. M., De Biase, A., Fattorini, S., Piattella, E., Sindaco, R., Venchi, A. \& Zapparoli, M., 1999. A proposal for a chorotype classification of the Near East fauna, in the framework of the Western Palearctic region. Biogeographia, 20: 31-59. 